\title{
Ownership structure as a measure of corporate performance
}

\author{
Slobodan Marić \\ University of Novi Sad, Faculty of Economics in Subotica, Subotica, Serbia \\ Ozren Uzelac \\ University of Novi Sad, Faculty of Economics in Subotica, Subotica, Serbia \\ Maja Strugar Jelača \\ University of Novi Sad, Faculty of Economics in Subotica, Subotica, Serbia
}

\begin{abstract}
Economic transition is not a one-dimensional process but implies ownership, structural and management transformation. We can call the current circumstances of the economy of the Republic of Serbia posttransitional, for which the ownership transformation is largely due. The aforementioned process is the basis for the formation of a corporate sector in which all the most important determinants of professional management are expressed, since the capital market represents the greatest distance between ownership and management. The structure of corporate ownership determines the nature of the relationship between managers and shareholders, which in the final instance manifests in the form of principal - principal or principal - agent of the situation.

The paper will analyse the nature of the ownership structure of corporations, according to one of the usual three dimensions (concentration of ownership), in relation to the corporate performance. The corporate performance will be expressed using the Tobin's $Q$ indicators. The structure of ownership of the corporation will be presented using two sets of indicators. The first group consists of indicators of percentage participation of a number of major shareholders in the form of Top 1, Top 2, Top 3 and Top 5. Another approach to property ownership analysis includes G1 (widely held) indicators that represent dispersed -owned corporations, G2 corporations with large shareholders, and G3 (ultimate owner) majority-owned corporations. In the random sample will be selected corporations that have a listing on the Belgrade Stock Exchange, while at the level of parametric statistical procedures, methods will be used for analysingthe correlation between the listed variables and identifying the differences between the groups formed on the basis of the above mentioned criterion.

The main objective of the paper is to define the ownership structure of a corporation that has direct implications for the management and performance of corporations. Corporate performance expressed through market capitalization determines the future of operations through the scope of future investments.
\end{abstract}

\section{Keywords}

Ownershipstructure, corporate management, performance, Serbia

Stockholders' meetings are a ceremony in which banality is varied chiefly by irrelevance 


\section{Introduction}

Formation of corporate sector in the Republic of Serbia began with the process of privatization, and the first forms of transformation of public property, and different models of this process determined the structure of ownership of corporate sector. The other model of privatization, implemented in 1997, implied free distribution of shares which formed a principal - agent situation in the corporate sector, that is, created circumstances where a large number of small shareholders did not have an adequate mechanism of influence, or a way to exercise the right to a decision. In the conditions of great dispersion of ownership, widely held professional management uses the dominant position in the above mentioned relationships, realising their personal interests and neglecting shareholders' interests, resulting in the fact that ownership becomes marginalised in corporate operation, which is one of the paradoxes in the functioning of the corporate form of companies, as it leaves significant consequences on exercising the right of return on equity, that is, the dividend. Bearing in mind the above situation, the third model of privatization was applied in 2001, where the majority package is sold to a strategic investor, thus solving a situation where managers do have domination, but new circumstances are formed, those of significant presence of large or ultimate owners, placing the minority shareholders in an identical situation like in the previous case. These circumstances open the dilemma of how to regulate the behaviour of large shareholders so as to protect the interests of a large number of small shareholders without stepping into the original problem (Becht, Bolton, \& Röell, 2003). Such and similar circumstances make a significant impact on providing new financing sources and market capitalization, as the low level of ownership rights does not attract investors and future investment in these corporations. No wonder, therefore, that the governments of the countries show a great interest in the inflow of foreign capital and create favorable conditions for investors (Ślusarczyk, 2018). Such paradoxical situations are especially expressed in now post-transition countries due to poor development of legal and institutional framework regulating the functioning of capital market and the corporate sector.

What we first associate with corporations is the highest level of professionalization of management based on the basic criterion of distinction of ownership and management, which is the most expressed in this corporate form. Thisseparation of ownership and management in this case is a very complex, both institutional and extra-institutional mechanism of capital market. At the same time, regardless of the aforementioned situation of separation of two categories, there is also a significant connection, as the nature of the ownership achieves a direct impact on corporate management. Thus, ownership structure, that is, degree of concentration of ownership, is brought into a direct connection with the business result of the corporation, as structure/concentration of ownership represents the direct mechanism of corporate management.

In view of all of the above, a permanently relevant question, regardless what time it comes from, is: who controls modern corporations, shareholders or managers (Berle \& Means, 1932)? The past decades have seen an accumulation of evidence on how power in modern corporations is transferred from the owners to managers, whereas the power of shareholders obviously wanes increasingly. Only a small part of the total value of shares appears at stockholders' meetings, those ceremonies in which banality is varied chiefly by irrelevance (Galbraith, 1972). Viewing from the current perspective, it must be admitted that a significant, and long-term, if not permanent transfer of power from owners of capital of managers. Impact of this power can also be viewed outside today's corporation, and then we mean influence on the entire society. To avoid the sensationalism of the above claims as soon as possible and give a down-to-earth explanation of these trends, it suffices to say that it is only about the continuation of transfer of power from one factor of production on another. As power used to imply ownership of land, which lost its primacy as the strategic factor of production, source of power and social position.

The basic motive of movement of power from one factor of production to another is the rarity criterion. Thus, the power goes to the production factor that is the least available, impossible or the most difficult to substitute. Such trends are imposed by the achieved level of technological development, degree of accumulated knowledge in the form of technology transferring the power from one production factor to another and thus determines which one will be dominant. This path 
is natural and represents a logical process within the civilizational development. So, contemporary technology sets new demands before powerful corporations, so that they can provide sustainable development, which is disposal of highly specialised, and, above all well-organized workforce. This requirement is significantly beyond the control of modern corporation, which does not apply when it comes to capital as a production factor, as it is owing to capital that corporations of today have reached the limits of power they possess, and, before all, significant independence. Thus, today, highly specialized workforce represents a production factor for the corporation it secures in external environment, which, above all, means that it is not independentand cannot create by itself. Thus, possession of capital by corporation in modern business environment does not mean warranty and security in providing highly specialized workforce, which represents a sufficient reason to relate criterion of rarity to human factor, and, by itself, the basic condition of poser of modern corporations.

Based on the above stated opinions, it is easy to recognise that it is a new process of transfer of power from one production factor to another, in this case, from capital to organisational knowledge, as the individual, whom we would term intrapreneur, is not in the focus. In the current circumstances, the intrapreneur or corporate entrepreneur has lost superiority that used to characterize him at the time of his domination. These abilities have no value today. What demands changes is man that has become a knowledge worker, carrier of value of the major part of the company's assets in the form of intellectual capital, highly educated individual, specialist or expert (Stojanović \& Marić, 2018). The core issue here is that power, in fact, transferred to an entirely new production factor, that is, a well-organized group of individuals possessing specialized knowledge from different areas, which, joined and well organized, form the basis of corporate performance. The issue is reflected in the fact that it requires the level of knowledge that will meet actual technological requirements, which is by no means knowledge that is or can be possessed by an individual, which is organisational associated and well organized wisdom of crowds. This process has been present for the entire past century, having reached the peak in the current conditions, and, as a factor of production makes a source of sustainable competitiveness. In the context of this research, the segment of organizational knowledge is referred to as management knowledge, representing a new source of corporate power, neglecting the ownership structure and degree of ownership concentration. Empirical and secondary data are employed to support the claim that cognitive economics does not concentrate on the distribution of current informational resources but on the creation of novel knowledge (Sponte, 2018). The aim of this paper is to estimate the relative impact of ownership structure, viewed through the dimension of concentration of ownership on the success of corporate management expressed through corporate performance. In accordance with this, we ask the following research question:

$R Q:$ To which extent does the degree of concentration of ownership determine corporate performance?

The remaining content of this work is organised within the following structure: the following section of the work analyses the relevant literature from the defined research area in order to define the research hypothesis. This is followed by the section that represents a way of sample selection, data gathering, before deriving final conclusions in order to realise the basic research aspirations.

\section{Theoretical basis of the paper - concentration of ownership as a control mechanism of corporate performance}

It is a fact that a significant part of the literature in the research of this work, there is a multitude of contradictory opinions and research, gives space and justifies new research into the topic of impact of ownership concentration on corporate performance. Economic transition towards market economy is absolutely incomplete without the process of ownership transformation (Barberis et al., 1996, Shleifer \& Vishny, 1996), This, however, is not only an issue of form, as market economy will not function without relevant institutions and intellectual capital, that is, to put it more completely, development of capital market, development of institutional and legal structure, as well as growth of intellectual capital, conditions are required that will make market economy more efficient (Stiglitz, 1999). Writing on economic transformation without mentioning the superior transition model of Chinese economy known as dual-track approach, which implied or phasing in or gradual process as the basic strategy 
of the reform of public property (Kang \& Kim, 2012), is not universally applicable in all former socialist countries due to significant specificities of these economic systems.

Shleifer and Vishny (1986) point out the positive impact of concentration of property on corporate result, which is exclusively based at the expense of the interest of small and in favour large and majority stakeholders, as opined by Holderness and Sheehan (1988), Barclay and Holderness (1989), Shleifer and Vishny (1997), which directly aggravates financing and issuing new shares. If such circumstances exist in a corporation, consequences are also manifested in the short run in the form of jeopardized liquidity, which, in any case does not bypass the success of management, which is the most indicative through market capitalization (Holmstrom and Tirole, 1993). However, highly respectable authors in this research area, Demsetz and Lehn (1985) do not confirm the connection between concentration of ownership and profit, whereas McConnell and Servaes (1990) point out that there is no correlation between market capitalization and costs of property. Thus, Holderness (2003) derives a general standpoint where he points out that there is no generally present positive or negative impact of property concentration on market capitalization.

Viewing the impact of property concentration on corporate performance from the angle of dynamic perspective and national conditions of business operations and degree of development of national economy, Nguyen, Locke and Reddy (2015) point out that there is a stronger correlation of the degree of property concentration in underdeveloped countries than in countries of higher degree of development, explaining this situation in the manner that the mechanism of corporate management can substitute for the weaknesses of national management. The authors of this paper accept the factual part of the above research results, which point out the stronger correlation between property concentration and corporate performance in underdeveloped countries compered to countries of higher degree of development, but they do not with the offered justification. Namely, the authors of this paper (Marić, Uzelac and Strugar Jelača) accept the existence in the strength of correlation between the observed phenomena, but state as explanation that power in less developed countries is concentrated on capital as production factor, which is why a significant section of corporate business performance stems from control over capital, in this case equity. Whereas in most countries of the third degree of development, with a lower degree of control over capital and corporate performance is the consequence of transfer power from capital to the new production factor, organisational knowledge, as explicitly represented in the introductory part of the paper. In the statements of the previous authors, dynamic perspective is interpreted in such a way that the current management structure and performance are determined by past performance (Wintoki, Linck \& Netter, 2012).

Contrary research results are found in $\mathrm{Li}, \mathrm{Lu}$, Mittoo and Zhang (2015), who point out that a lower level of ownership concentration, at the same time, means a greater independence of corporate management and a higher level of corporate performance. Such results can be explained by a higher degree of development of corporate sector in terms of a whole as a corporate culture that prevails in economy, which was the subject of this research. It is necessary to point out here that corporate performance differs depending on the nature of ownership, where positive results go in favour of the private in comparison with pubic.

There are actual research results, such as Kumar and Zattoni (2013), Filatotchev, Jackson and Nakajima (2013), among others, who refer to research and existence of interaction of the level of natural development of the country and organizational variables in studies on corporate management. Thus, Wang and Shailer (2015) point out the need for future corporate research on the relation between ownership structure and corporate performance in developing countries, which they confirm with results of their own research that this topic in the mentioned framework remains a controversial issue. This conclusion is not only a consequence of disagreement in theoretic opinions, but also contradictory results of empiric research.

\subsection{The control variable}

The feature included in the analysis of research as a control variable is the size of corporation, as this criterion directly determines competitiveness. The size of the corporation is measured by value of property, that is, size of the assets of the balance sheet. Large corporations are expected to possess a higher level of profitability owing to economies of scale, as well as all other advantages stemming from the corporation's economic power, and, 
above all, possessing a significant capacity for absorbing business risk. A higher level of corporate competitiveness influences a higher level of market capitalization, which directly determines future business operations by attracting new investors more successfully.

\section{Methodology}

\subsection{Sample and data}

The sample is comprised of 150 corporations (joint stock companies) selected by a defined criterion of randomness, listed on the Belgrade Stock Exchange. Data required for research was collected from three sources. Data on the value of market capitalization of equity Belgrade Stock Exchange (Beogradska berza, 2019), data on ownership structure from the Central Register, Depot and Clearing of Bonds (Centralni registar, depo i kliring hartija od vrednosti, 2019), data on the total value of corporate property, financial reports - latest available balance sheet, Business registers Agency (Agencija za privredne register, 2019).

\subsection{Variables and quantitative procedures}

Having overviewed the literature on the research area in the choice of the measures of structure/ownership structure, the dominant approach is of Demsetz and Lehn (1985), grouping shareholders into 5 major or 20 major shareholders as the percentage of ownership share in the total equity, and $\mathrm{AH}$ as Herfindahl index of ownership concentration, which is calculated as the sum of squares of the percentage of shares controlled by every individual shareholder. Another frequently used measure of ownership concentration is extraction of majority shareholders (ultimate owners) (Holderness \& Sheehan, 1988) or recognising the percentage share of the major shareholder (Claessens, Djankov, Fan, \& Lang, 2002) as a measure (Claessens et al., 2002). While Prowse (1992), Hovey, Li and Naughton (2003) point out a separate measure of percentage of five largest shareholders. What is important to point out when selecting appropriate measures of ownership concentration, especially in the case of measures based on groups of the largest shareholders, attention needs to be paid to whether there is a majority owner. In such situations, where we have the presence of a majority owner, when carrying out certain research and defining the impact of ownership structure on corporate management and corporate performance, its influence is far more significant than the influence based on the meassures of a certain group of shareholders. While measuring the influence of the group is significant only in satiation when we have several major shareholders who can exercise control over corporation. For this reason, the authors opted for analysis of impact of owner concentration based on both approaches.

Table 1. Overview of variables included in research

\begin{tabular}{l|l}
\hline Variable & Definition \\
\hline Tobin's Q & $\begin{array}{l}\text { measure of corporate performance - coefficient of market capitalisation: value of market capitalisation of } \\
\text { equity / book value of the total assets }\end{array}$ \\
\hline Top_1 & $\%$ share in the total issue of the largest shareholder with voting rights \\
\hline Top_2 & $\%$ share in the total issue of two largest shareholders with voting rights \\
\hline Top_3 & $\%$ share in the total issue of three largest shareholders with voting rights \\
\hline Top_5 & \% share in the total issue of five largest shareholders with voting rights \\
\hline ComSize & Size of corporation measured by total assets \\
\hline Group 1 & $\begin{array}{l}\text { Group of corporations with small shareholders or with dispersed ownership (widely held), where the } \\
\text { share of the largest shareholder does not exceed } 20 \% \text { shares of the largest shareholder }\end{array}$ \\
\hline Group 2 & $\begin{array}{l}\text { Group of corporations with a great shareholder where the share of the largest shareholder exceeds 20\% } \\
\text { of shares with voting right, but is lower than } 50 \%\end{array}$ \\
\hline Group 3 & $\begin{array}{l}\text { Group of corporations with majority shareholder (ultimate owner), where the share of the largest } \\
\text { shareholder exceeds } 50 \% \text { of shares with voting right. }\end{array}$ \\
\hline
\end{tabular}

With respect to research intention, the ultimate goal of corporate management is achieving longterm shareholder value; such an income can be expected if the best management practices are adopted, which will leave direct consequences on corporate performance (Anum Mohd Ghazali,
2010). The choice of Tobin Q's coefficient as a corporate performance measure is essential for several reasons (Demsetz \& Villalonga, 2001). Above all, it includes future time perspective in the form of forward-looking approach, as this is the base of performance approach in terms of 
business opportunities in achieving the set goals, but viewed at the moment of setting goals, that is, from the perspective of the present. This approach is far more sensible in assessing goals that managers should achieve. The following reason that gives advantage to the chosen measure; in the case of Tobin's Q coefficient, they are future investors who use the chosen measure to express the level of confidence of the business environment and all the stakeholders in the corporation.

Standard multiple regression as a method applied in this paper enables predicting the expected outcome of a given set of predictor variables of property concentration (as continuous variables), as well as which variable viewed individually, represents the best predictor of business performance. Bearing in mind the specific features of this method, we set the following research assumption:

H1: There is a positive correlation connection at the level of statistical significance between measures of ownership concentration and the measure of corporate performance;

The other method that we opt for is MANOVA, whose application is enabled by the nature of variables of concentration of property (as a categorical variable and all other subsequent procedures implied by the entirety of the calculative procedure based on the selected method. Bearing in mind the specific features of this method, we set the following research assumptions:

H2: There is a statistically significant difference between defined groups of corporations in relation to the observed variables;

H2a: There is a precisely defined border between the defined groups of corporations in relation to the observed variables;

$H 2 b$ : There is a statistically significant difference between defined groups of corporations by individual characteristics.

\section{Analysis of research results and discussion}

The significance of this topic and nature of research in the Republic of Serbia is reflected, firs of all, due to the development phase of the social and economic system, and, in accordance with this, identifying the basic specific features of the corporate sector. The analysis of these positions in the previous sections of the paper confirms the currency and worthwhileness of this type of research, and, above all, the effort do offer an appropriate answer to the set research question based on research results. The concept of research was defined the selected measures of the observed phenomena to a significant extent.

Table 2. Descriptive statistics of selected variables for the application of multiple regression

\begin{tabular}{l|r|r|r}
\hline & \multicolumn{1}{|c|}{ Mean } & Std. Deviation & $\mathrm{N}$ \\
\hline Tobins Q Ratio (Market Values/Asset Book Value) &, 5049 &, 89658 & 146 \\
\hline \% share of the first shareholder Top_1 & 58,9897 & 24,87023 & 150 \\
\hline \% share of the first two shareholders Top_2 & 70,4373 & 21,57453 & 150 \\
\hline \% share of the first three shareholders Top_3 & 74,9330 & 19,82014 & 150 \\
\hline \% share of the first five shareholders Top_5 & 78,4925 & 18,84817 & 150 \\
\hline Asset Book Value & 1023585415,0068 & 2123286779,45398 & 147 \\
\hline
\end{tabular}

Source: The authors' calculation

The first approach to measuring property concentration based on measures Top_1, Top_2, Top_3 and Top_5, including the measure of corporate performance Tobins $\mathrm{Q}$ ration and measure of size of corporation Asset Book Value forms a model for application of multiple regression so as to determine how well the set of variables of property concentration and size of corporation predicts corporate performance. Given that standard multiple regression as a method is highly sensitive to defined assumption, multicolinearity as one of the basic features makes the model unacceptable, as variables Top_1, Top_2, Top_3 and Top_5, as independent variables are highly correlated with the value of coefficient $r>0.9$, value of Tolerance $<0.10$ and value of VIF at a high value above borderline value 10 . This correlation is a consequence of a high level of property concentration, where $2 / 3$ of corporations in the sample have a majority owner, implying absolute control, so that the remaining measures do not reflect a different nature, which can all be seen based on the mean vales of other measures presented in Table 2. As regards the measures of ownership concentration, the approach of Demsetz and Lehn (A5, A20, AH index) is applicable in countries where there is a high dispersion of ownership in the corporate sector. In countries with underdeveloped corporate sector and capital market, significant 
ownership concentration, which predominantly represent the specific feature of post-transition economic circumstances, it is of great importance to analyse the impact of the majority shareholder (Earle, Kucsera, \& Telegdy, 2005). By reducing the model for variables that do not meet the condition of multicolinearity, which are, due to high ownership concentration, essentially not different from variable Top 1, we got the results of correlation analysis shown in Table 3 .

Valuation of the acquired model, which is done based on square value of the coefficient of determination which is in Table 3 and amounts to $r 2=0.033$. This value points to what section of the variance of the dependent variable explains the set model. Expressed in percentage, the coefficient has the value of $3.3 \%$, which means that $3.3 \%$ of corporate performance is explained by the set model, which is a very low value for this type of research.
Table 3. Model Summary ${ }^{\mathrm{b}}$

\begin{tabular}{r|r|r|r|r}
\hline Model & R & $\begin{array}{r}\text { R } \\
\text { Square }\end{array}$ & $\begin{array}{c}\text { Adjusted } \\
\text { R Square }\end{array}$ & $\begin{array}{r}\text { Std. Error of the } \\
\text { Estimate }\end{array}$ \\
\hline 1 &, $183^{a}$ &, 033 &, 020 &, 88766 \\
\hline \multicolumn{4}{c}{ a. Predictors: (Constant), Asset Book Value (equity book value), } \\
\% share of the first shareholder \\
b. Dependent Variable: Tobins Q Ratio \\
(Market Values/Asset Book Value) \\
Source: The authors' calculation
\end{tabular}

When rejecting the method, apart from going in favour of the property concentration, we assessed to which extent the value of coefficient of determination is statistically significant for the set model, which is presented in Table 4, ANOVA, with the results of the test of the $0^{\text {th }}$ hypothesis that $\mathrm{r} 2=0$. Given that the value Sig $=0.089$, which means in fact, that the model does not reach statistical significance. All the previously analysed results obtained by application of standard multiple regression point to rejection of $\mathrm{H} 1$.

Table 4. ANOVA

\begin{tabular}{l|l|r|r|r|r|r}
\hline \multicolumn{2}{l|}{ Model } & Sum of Squares & df & Mean Square & F & Sig. \\
\hline \multirow{3}{*}{1} & Regression & 3,883 & 2 & 1,942 & 2,464 &, $089^{b}$ \\
\cline { 2 - 7 } & Residual & 112,676 & 143 &, 788 & & \\
\cline { 2 - 7 } & Total & 116,559 & 145 & & & \\
\hline \multicolumn{6}{c}{ a. Dependent Variable: Tobins Q Ratio (Market Values/Asset Book Value) } \\
b. Predictors: (Constant), Asset Book Value ((equity book value), \\
\% share of the first shareholder \\
Source: The authors' calculation
\end{tabular}

In view of the opinions of Demsetz and Lehn, we include the second approach in the choice of measure of property concentration, in other words, mostly present majority shareholder, due to which the above stated approach loses significance. The second approach points to establishing the difference between groups of corporations G1, G2 and G3 (La Porta, Lopez $\square$ de $\square$ Silanes, \& Shleifer, 1999) in relation to corporate performance expressed in Tobin's Q coefficient.

Procedures of unifactorial multivariate variance analysis was used to examine the differences between the defined groups of corporations according to the above stated criterion characteristic of ownership concentration in relation to the selected dependent variables, Asset Book Value, Tobins Q Ratio i Top_1.

Based on the results from Table 5, a statistically significant difference was established between groups of corporations G1, G2, and G3 in relation to linear combination of dependent variables, $F(2,282.000)=56,553$, Wilks' lambda 0.206 with statistical significance $\mathrm{p}=0.000$ (Tabachnick \& Fidell, 2007). These results point to acceptance of hypothesis $\mathrm{H} 2$.

Out of the results of discriminant analysis F (2, $141.000)=217,311$, which is pointed to by value ) $=217,311$, we conclude that there is a clearly defined border between the observed groups of corporations as an independent characteristic in relation to selected variables. These results point to acceptance of hypothesis $\mathrm{H} 2 \mathrm{a}$.

Table 5. MANOVA and discriminant analysis in relation to group of dependent variables

\begin{tabular}{r|r|r|r}
\hline Analysis & $\mathbf{n}$ & $\mathbf{F}$ & $\mathbf{p}$ \\
\hline MANOVA & 3 & 56,553 & .000 \\
\hline discriminant & 3 & 217,311 & .000 \\
\hline
\end{tabular}


The results of the above quantitative procedures pointed to the differentiation and existence of limits between the categories of criterion characteristic of the observed phenomenon, thus leading to the subsequent steps in the analysis and considering dependent variables separately.

Table 6. Tests of Between-Subjects Effects

\begin{tabular}{|c|c|c|c|c|c|c|c|}
\hline Source & Dependent Variable & Type III Sum of Squares & $\begin{array}{l}\mathrm{d} \\
\mathrm{f}\end{array}$ & Mean Square & $\mathrm{F}$ & Sig. & $\begin{array}{l}\text { Partial Eta } \\
\text { Squared }\end{array}$ \\
\hline \multirow{3}{*}{ Group } & Asset Book Value & $\begin{array}{r}4487160184829640700,0 \\
00 \\
\end{array}$ & 2 & $\begin{array}{r}2243580092414820350,00 \\
0 \\
\end{array}$ & ,492 & $\begin{array}{r}, 61 \\
3 \\
\end{array}$ & ,007 \\
\hline & Tobins Q Ratio & ,935 & 2 & ,468 & ,578 & $\begin{array}{r}, 56 \\
2 \\
\end{array}$ & ,008 \\
\hline & Top_1 & 69165,110 & 2 & 34582,555 & $\begin{array}{r}271,36 \\
0 \\
\end{array}$ & $\begin{array}{r}, 00 \\
0 \\
\end{array}$ & ,791 \\
\hline
\end{tabular}

The results of the analysis and consideration of dependent variables separately is presented in Table 6, which were obtained based on univariate procedures, in the form of indicator $\mathrm{F}$, number of degrees of freedom $\mathrm{df}$ and margin of error of the first type. ANOVA analysis aims to establish the difference between the defined groups of corporations based on each individual characteristic, as well as contribution to the established difference of each dependent characteristic by means of indicator Partial Eta Squared.

Table 7. Descriptive Statistics

\begin{tabular}{l|l|r|r|r}
\hline & \multicolumn{1}{|c|}{$\begin{array}{c}\text { Groups of } \\
\text { shareholders }\end{array}$} & \multicolumn{1}{c|}{ Mean } & Std. Deviation & N \\
\hline \multirow{4}{*}{ Asset Book Value } & G1<20\% & 1267423000,0000 & 1556973768,00721 & 8 \\
\cline { 2 - 5 } & G2>20\% & 740246710,5263 & 1724591026,99752 & 38 \\
\cline { 2 - 5 } & G3>50\% & 1121972200,0000 & 2304286044,78724 & 100 \\
\cline { 2 - 5 } & Total & 1030588897,2603 & 2128891472,28836 & 146 \\
\hline \multirow{5}{*}{ Tobins Q Ratio } & G1<20\% &, 3600 &, 36512 & 8 \\
\cline { 2 - 5 } & G2>20\% &, 3932 &, 33838 & 38 \\
\cline { 2 - 5 } s3>50\% of share of the first & G3 &, 5590 & 1,05626 & 100 \\
\cline { 2 - 5 } & Total &, 5049 &, 89658 & 146 \\
\hline & G1<20\% & 9,5163 & 6,21759 & 8 \\
\cline { 2 - 5 } & G2>20\% & 32,3895 & 7,91137 & 38 \\
\cline { 2 - 5 } & G3>50\% & 74,0788 & 12,56809 & 100 \\
\cline { 2 - 5 } & Total & 59,6905 & 24,54964 & 146 \\
\hline
\end{tabular}

Having analysed the results of Table 6, we can conclude that hypothesis $\mathrm{H} 2 \mathrm{~b}$ is partially accepted, as the contribution to the existence and precise disambiguation of the defined groups of corporations, out of three independent characteristics, only the characteristic $\%$ of participation of the largest shareholder with values $F(2,143)=271.360$, statistical significance at the level $\mathrm{F}(2,143)=271.360$, and value Partial Eta Squared 0,791 contributes to the above mentioned research assumption.

\section{Conclusion}

In the context of this research, the primary observed characteristic in the form of Tobins Q
Ratio as a measure of corporate performance did not contribute do differentiating groups of corporations with more than $50 \%$ shares with a voting right, large shareholder with more than $20 \%$ of voting rights, and minority shareholders whose percentage of participation in equity does not exceed $20 \%$. Based on the above, we can concluded that the essential difference between majority, minority and small shareholders can form the majority package of shares and achieve control over corporation. This situation can further be explained that, due to express high ownership concentration (as seen in Table 7, descriptive statistic and dominant influence of majority or several large shareholders, equity does 
not receive appropriate market verification, as pointed to low values of indicator Tobins Q Ratio, primarily as a consequence of the present principal - principal situation, influencing the low level of confidence of potential investors and low level capitalization level of equity.

Thus, in accordance with the situation that the corporate sector is, capital market only becomes mechanism or redistribution of property rights, which should be the secondary function, whereas primary function in the form of mechanism of financing this sector almost does not exist.sm

\section{References}

Agencija za privredne registre. (2019). Finansijski izveštaji. Retrieved March 04, 2019 from: http://www.apr.gov.rs/

Anum Mohd Ghazali, N. (2010). Ownership structure, corporate governance and corporate performance in Malaysia. International Journal of Commerce and Management, 20 (2), 109-119. https://doi.org/10.1108/10569211011057245

Barberis, Nocholas, Boycko, Maxim, Shleifer, Andrei, \& Tsukanova, Natalia (1996). How does privatization work? Evidence from the Russian shops. Journal of Political Economy, 104 (4), 764-790. https://doi.org/10.1086/262042

Barclay, M. J., \& Holderness, C. G. (1989). Private benefits from control of public corporations. Journal of financial Economics, 25 (2), 371-395. https://doi.org/10.1016/0304-405X(89)90088-3

Becht, M., Bolton, P., \& Röell, A. (2003). Corporate governance and control. In G. M. Constantinides, M. Harris, R. M. Stulz (Eds.), Handbook of the Economics of Finance (pp. 1-109). London: Elsevier. https://doi.org/10.1016/S1574-0102(03)01005-7

Beogradska berza. (2019). Pokazatalji. Retrieved March 04, 2019 from: https://www.belex.rs

Berle, A. A., \& Means, G. C. (1932). The modern corporation and private property. New Brunswick. NJ: Transaction.

Centralni registar, depo i kliring hartija od vrednosti. (2019) Statistika vlasništva akcionarskih društava. Retrieved March 04, 2019 from: http://www.crhov.rs/

Claessens, S., Djankov, S., Fan, J. P., \& Lang, L. H. (2002). Disentangling the incentive and entrenchment effects of large shareholdings. The journal of finance, 57 (6), 2741-2771. https://doi.org/10.1111/1540-6261.00511

Demsetz, H., \& Lehn, K. (1985). The structure of corporate ownership: Causes and consequences. Journal of political economy, 93 (6), 1155-1177. https://doi.org/10.1086/261354

Demsetz, H., \& Villalonga, B. (2001). Ownership structure and corporate performance. Journal of corporate finance, 7 (3), 209-233. https://doi.org/10.1016/S0929-1199(01)00020-7

Earle, J. S., Kucsera, C., \& Telegdy, Á. (2005). Ownership concentration and corporate performance on the Budapest stock exchange: Do too many cooks spoil the goulash?. Corporate Governance: An International Review, 13 (2), 254-264. https://doi.org/10.1111/j.1467683.2005.00420.x
Filatotchev, I., Jackson, G., \& Nakajima, C. (2013). Corporate governance and national institutions: A review and emerging research agenda. Asia Pacific Journal of Management, 30 (4), 965-986. https://doi.org/10.1007/s10490-012-9293-9

Galbraith, J. K. (1967). 1972 The new industrial state. Boston: Houghton Mifflin Harcourt.

Holderness, C. G. (2003). A survey of blockholders and corporate control. Economic policy review, 9 (1). http://dx.doi.org/10.2139/ssrn.281952

Holderness, C. G., \& Sheehan, D. P. (1988). The role of majority shareholders in publicly held corporations: An exploratory analysis. Journal of financial economics, 20 , 317-346. https://doi.org/10.1016/0304-405X(88)90049-9

Holmström, B., \& Tirole, J. (1993). Market liquidity and performance monitoring. Journal of Political Economy, 101 (4), 678-709. https://doi.org/10.1086/261893

Hovey, M., Li, L., \& Naughton, T. (2003). The relationship between valuation and ownership of listed firms in China.Corporate Governance: An International Review, 11 (2), 112-122. https://doi.org/10.1111/1467-8683.00012

Kang, Y. S., \& Kim, B. Y. (2012). Ownership structure and firm performance: Evidence from the Chinese corporate reform. China Economic Review, 23 (2), 471-481. https://doi.org/10.1016/j.chieco.2012.03.006

Kumar, P., \& Zattoni, A. (2013). Howmuch do country-level or firm-level variablesmatter in corporate governance studies? Corporate Governance: An International Review, 21(3), 199-200. https://doi.org/10.1111/corg.12025

La Porta, R., Lopez-de-Silanes, F., \& Shleifer, A. (1999). Corporate ownership around the world. The journal of finance, 54 (2), 471-517. https://doi.org/10.1111/0022-1082.00115

Li, K., Lu, L., Mittoo, U. R., \& Zhang, Z. (2015). Board independence, ownership concentration and corporate performance-Chinese evidence. International Review of Financial Analysis, 41, 162-175. https://doi.org/10.1016/j.irfa.2015.05.024

McConnell, J. J., \& Servaes, H. (1990). Additional evidence on equity ownership and corporate value. Journal of Financial economics, 27 (2), 595-612. https://doi.org/10.1016/0304-405X(90)90069-C

Nguyen, T., Locke, S., \& Reddy, K. (2015). Ownership concentration and corporate performance from a dynamic perspective: Does national governance quality matter? International Review of Financial Analysis, 41, 148-161. https://doi.org/10.1016/j.irfa.2015.06.005

Prowse, S. D. (1992). The structure of corporate ownership in Japan. The Journal of Finance, 47 (3), 1121-1140. https://doi.org/10.1111/i.1540-6261.1992.tb04007.x

Shleifer, A, \& Vishny, R. W. (1996). A survey of corporate governance. NBER Working paper. Retrieved February 12, 2019 from: https://www.nber.org/papers/w5554.pdf https://doi.org/10.3386/w5554

Shleifer, A., \& Vishny, R. W. (1986). Large shareholders and corporate control. Journal of political economy, 94 (3, Part 1), 461-488. https://doi.org/10.1086/261385 
Shleifer, A., \& Vishny, R. W. (1997). A survey of corporate governance. The journal of finance, 52 (2), 737-783. https://doi.org/10.1111/j.1540-6261.1997.tb04820.x

Ślusarczyk, B. (2018). Tax incentives as a main factor to attract foreign direct investments in Poland. Administratiesi Management Public, 30, 67-81. https://doi.org/10.24818/amp/2018.30-05

Sponte, M. (2018). Cognitive performance and labor market outcomes: evidence from the US. Economics, Management, and Financial Markets, 13 (2), 70-75. https://doi:10.22381/EMFM13220185

Stiglitz, J (1999). Whither reform?: Ten years of the transition. World Bank Annual Conference on Development Economics Dashington. Retrieved February 12, 2019 from:

http://documents.worldbank.org/curated/en/4486814687 41326292/pdf/multi-page.pdf

Stojanović S. \& Marić S. (2018). Komunikacija kao mera performanse liderstva, Anali Ekonomskog fakulteta $u$ Subotici, 54 (40), 81-94.

https://doi.org/10.5937/AnEkSub1840081S

\section{$\triangle$ Correspondence}

\section{Ozren Uzelac}

University of Novi Sad, Faculty of Economics in Subotica Segedinski put 9-11, 24000, Subotica, Republic of Serbia

E-mail: uzelacozren@ef.uns.ac.rs
Tabachnick, B. G., Fidell, L. S., \& Ullman, J. B. (2007). Using multivariate statistics. Boston, MA: Pearson.

Wang, K., \& Shailer, G. (2015). Ownership concentration and firm performance in emerging markets: A metaanalysis. Journal of Economic Surveys, 29 (2), 199-229. https://doi.org/10.1111/joes.12048

Wintoki, M.B., Linck, J.S., \& Netter, J.M. (2012). Endogeneity and the dynamics of internal corporate governance. Journal of Financial Economics, 105 (3), 581-606.

https://doi.org/10.1016/j.jfineco.2012.03.005 